\title{
Emphysematous cystitis: a radiographic diagnosis
}

\author{
Meriam Islam, ${ }^{1}$ Aaron Singh Bancil, ${ }^{2}$ Owen Ingram ${ }^{3}$
}

${ }^{1}$ Department of

Ophthalmology, Maidstone

District General Hospital,

Maidstone, UK

${ }^{2}$ Department of Hepatology,

Kings College Hospital,

London, UK

${ }^{3}$ Department of Orthogeriatrics,

Croydon University Hospital,

London, UK

\section{Correspondence to}

Dr Meriam Islam,

meriamislam@doctors.org.uk

Accepted 21 February 2016

\section{DESCRIPTION}

A 94-year-old woman under our care receiving treatment for Clostridium difficile colitis reported abdominal pain and frequency of urination. She had a soft abdomen with mild suprapubic tenderness. She had a background of diverticulitis and a recent admission with $C$. difficile-related pseudomembranous colitis. An abdominal radiograph (figure 1) demonstrated a thin rim of air throughout the bladder wall. A CT scan (figure 2) further illustrated this finding, consistent with a diagnosis of emphysematous cystitis (EC). Urine microscopy showed mixed coliform species. EC is defined as air within the bladder wall and lumen, associated with infection. ${ }^{1}$ EC is a relatively rare condition that has a significant mortality rate of $7 \%{ }^{2}$ It has a diverse presentation ranging from an asymptomatic patient as an incidental finding on imaging to severe sepsis. ${ }^{2}$ A definitive diagnosis can only be made on abdominal imaging, and CT is recommended as the primary imaging modality if EC is suspected, to define the severity of the disease and exclude ascending infections. ${ }^{2}$ Risk factors include a neurogenic bladder, diabetes mellitus and being of female sex. ${ }^{2}$ It is important for physicians to be aware of how this condition appears on abdominal imaging in order to facilitate swift diagnosis and implement effective medical management including: broad spectrum antibiotics, tight glycaemic control, adequate bladder drainage and management of concurrent comorbidities, to avoid the morbidity and mortality associated with this condition. ${ }^{2}$ Our patient received a 5-day course of co-amoxiclav, and her symptoms and repeat abdominal radiograph demonstrated complete resolution of her EC.

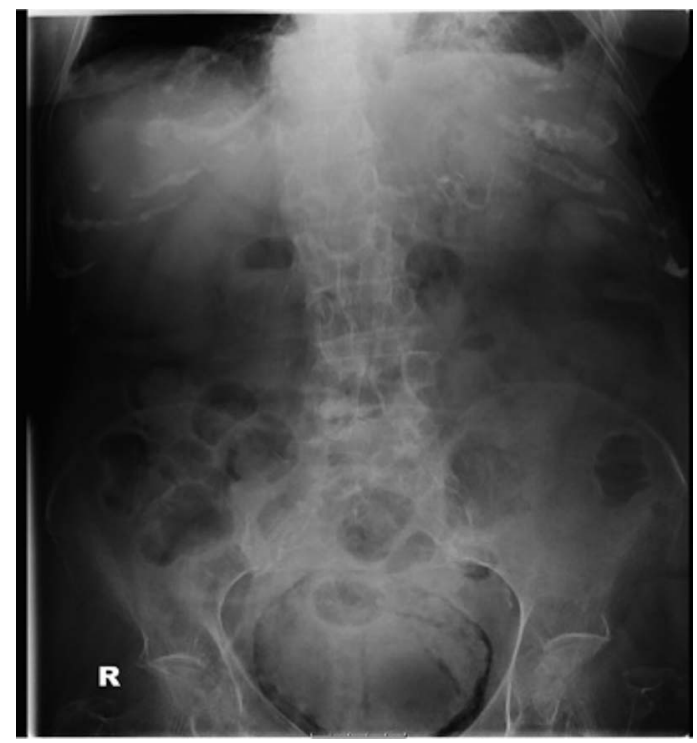

Figure 1 Abdominal X-ray demonstrating thin rim of air within the bladder wall.

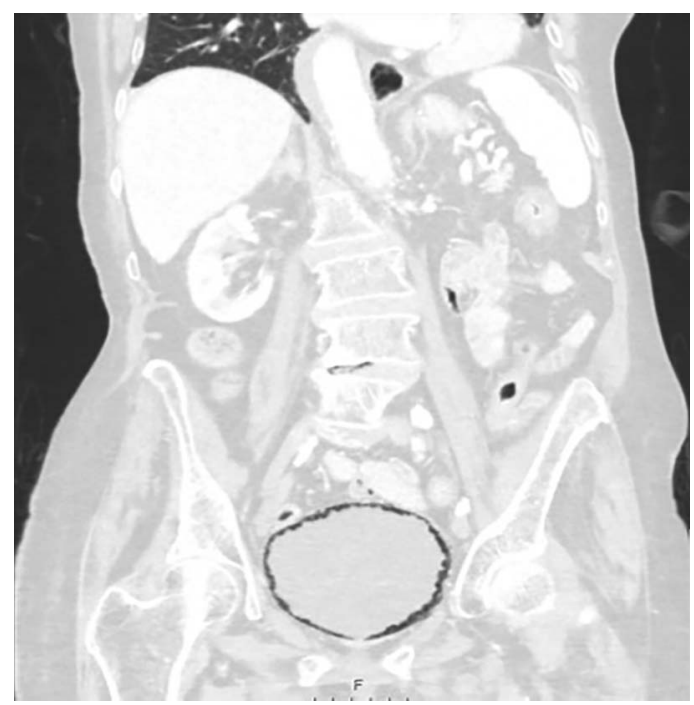

Figure 2 CT image highlighting air throughout the bladder wall.

\section{Learning points}

- Emphysematous cystitis is an uncommon condition with a diverse presentation and a significant mortality rate of $7 \%$.

- Risk factors for this condition include diabetes mellitus, being of female sex and a neurogenic bladder.

- Emphysematous cystitis can only be diagnosed definitively on abdominal imaging, and CT is recommended to assess severity and possible development of ascending infections.

- Awareness of this condition is essential as medical management must be implemented early to prevent a poor outcome.

Contributors $\mathrm{MI}$ and ASB were involved in substantial contributions to the conception or design of the work, or the acquisition, analysis or interpretation of data. $\mathrm{Ml}$ and Ol were involved in drafting the work or revising it critically for important intellectual content. $\mathrm{MI}$ and OI were involved in final approval of the version published. $\mathrm{MI}, \mathrm{OI}$ and $\mathrm{ASB}$ are in agreement to be accountable for all aspects of the work in ensuring that questions related to the accuracy or integrity of any part of the work are appropriately investigated and resolved.

Competing interests None declared.

Patient consent Obtained.

Provenance and peer review Not commissioned; externally peer reviewed.

\section{REFERENCES}

1 Amano M, Shimizu T. Emphysematous cystitis: a review of the literature. Intern Med 2014;53:79-82.

2 Thomas AA, Lane BR, Thomas AZ, et al. Emphysematous cystitis: a review of 135 cases. BJU Int 2007;100:17-20. 


\section{Images in...}

Copyright 2016 BMJ Publishing Group. All rights reserved. For permission to reuse any of this content visit http://group.bmj.com/group/rights-licensing/permissions.

BMJ Case Report Fellows may re-use this article for personal use and teaching without any further permission.

Become a Fellow of BMJ Case Reports today and you can:

- Submit as many cases as you like

- Enjoy fast sympathetic peer review and rapid publication of accepted articles

- Access all the published articles

- Re-use any of the published material for personal use and teaching without further permission

For information on Institutional Fellowships contact consortiasales@bmjgroup.com

Visit casereports.bmj.com for more articles like this and to become a Fellow 